Historic, Archive Document

Do not assume content reflects current scientific knowledge, policies, or practices. 


\section{(Tul1920 Lint)}
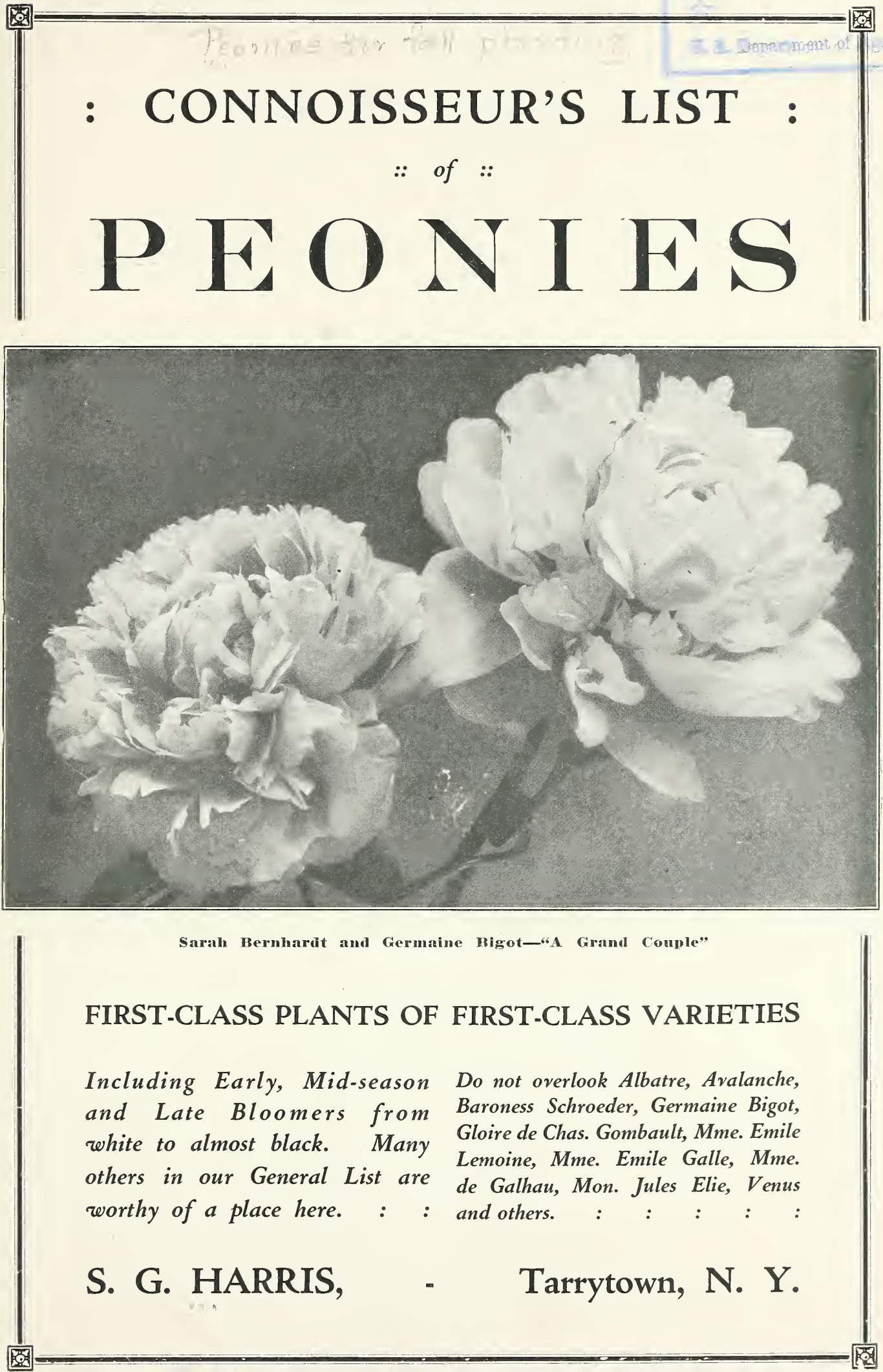


\section{Connoisseur's List}

\section{DOUBLE}

Elwood Pleas. Very soft, shell pink, large, fragrant and beautiful. Late..........\$ 6.00

wugene Bigot. (Dessert, 1894). Brilliant red, Medium size, compact, globular, semirose type. Midseason..................................

Eugene Verdier. (Calot, 1864). Very light pink with lilac-white collar. Large, rose type; extra strong-growing plant; erect, rather dwarf. Late. Be sure you get

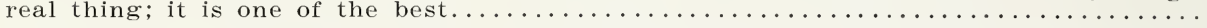

Kanl Rosenfield. (Rosenfield, 1908). Brilliant deep crimson. Very strong, tall, compact grower and free bloomer. One of the best. Semi-rose type; excellent keeper. Mid-

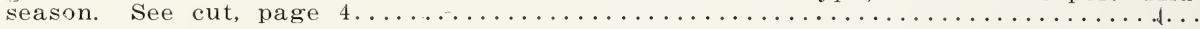

Lady Alexander Duf. (Kelway). Outer petals pale rose, gradually shading lighter toward center. An immense cup-shape flower; broad, imbricated petals, large and full in old plants. In young plants and the side buds of older plants, blooms are water lily shape, showing yellow stamens at center. Fragrant, tall and robust.

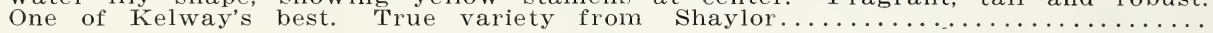

Laura Dessert. (Dessert, 1913). Guards cream white; center bright canary yellow.

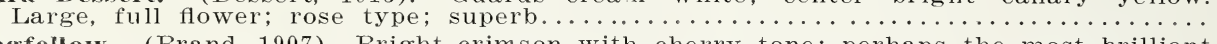

Longfellow. (Brand, 1907). Bright crimson with cherry tone; perhaps the most brilliant of red peonies. Erect habit, vivid color, long season, rare value. Originator says,

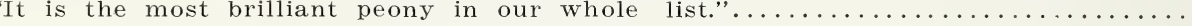

Mme. De Treyeran. (Dessert, 1889). Delicate flesh white, dotted with carmine. Large, flat, compact flower; tall; free bloomer; early

Inne. Jules Dessert. (Dessert, 1909). Clear pink, tinged flesh and straw yellow, undulated central petals flecked with carmine and intermixed with a few visible golden stamens. Very large, imbricated flower of fine shape; one of the most beautiful in color and form. When the flower opens under cloudy weather or in the house, the

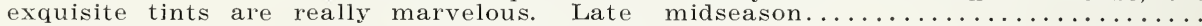

Mrae. Lemonier. (Calot, 1860). Exquisite pale rose-pink. Very large globular bloom, rose type; strong grower and very free bloomer. "The size of tlis peony, its great height, robust habit and fine color, make it a most striking garden subject." Mid-

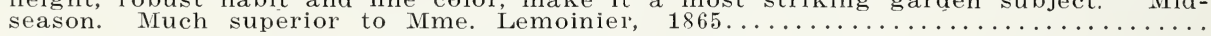

Harcelle Dessert. (Dessert, 1899). Milk white, slightly splashed with lilac; high

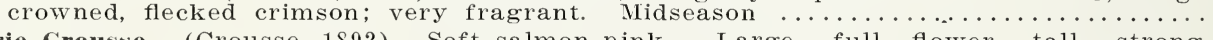

Marie Crousse. (Crousse, 1892). Soft salmon-pink. Large, full flower, tall, strong.

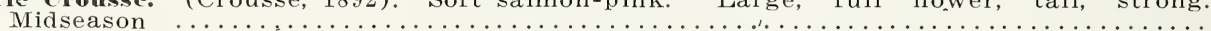

Milton Hill. (Richardson). Soft, clear, flesh color, deepening toward the center. "There is in this flower a quality of color that is beyond the power of words to describe." Very large globular, compact, rose type; strong grower; fragrant. Very late......

Mont Blanc. (Lemoine, 1899). Milk-white, center slightly tinted rose. Very large, com-

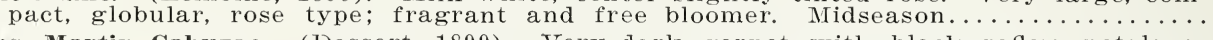

Ions. Martin Cahuzac. (Dessert, 1899). Very dark garnet with black reflex, petals so glossy as to appear varnished. Medium to large, globular, semi-rose type. Medium

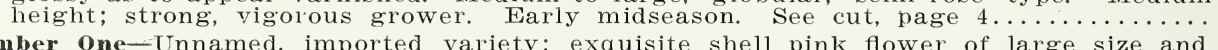

Number one-Unnamed, imported variety; exquisite shell pink flower of large size and beautiful form; center splashed with crimson after the manner of Festiva Maxima. Rose type; very late. It excels in attractiveness many of the highest priced

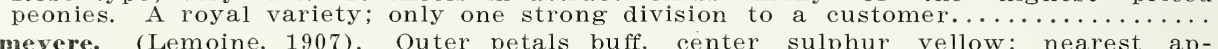

Primevere. (Lemoine, 1907). Outer petals buff, center sulphur yellow; nearest approach to a yellow peony. Tall, strong, grower, and free bloomer. Very fragrant,

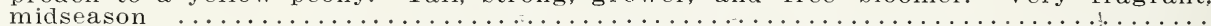

Ihaoul Dessert. (Dessert, 1910). Clear mauve, shaded carmine pink, and stained silvery white. Extremely large flower; strong grower; late midseason. Very fragrant...

Reine Hortense. (Calot, 1857). (Syn. President Taft). Pale rose-pink, very striking

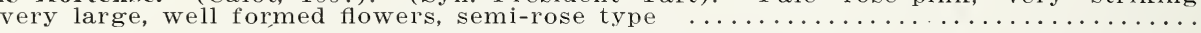

Rosa Bonheur. (Dessert). Fleshy pink, imbricated flower; rose type; dwarf plant;

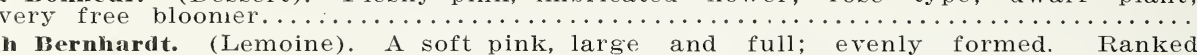

Sarah Bernhardt. (Lemoine). A soft pink, large and full; evenly formed. Ranked
among the twelve best peonies by twenty-three peony growers; one of Lemoine's

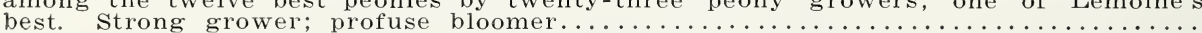

Solange. (Lemoine, 1907). The outer petals are very delicate lilac white, deepening toward the center with salmon shadings; center deep orange salmon. A very large, full, compact flower of rose type; strong grower and free bloomer; delightfully fra-

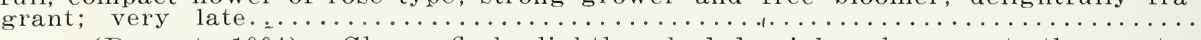

Therese. (Dessert, 1904). Glossy flesh, lightly shaded pink, clearer at the center. Very attractive imbricated flowers, very large and full, double; one of the most

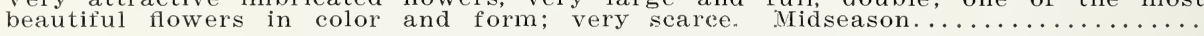

Tourangelle. (Dessert, 1910). Flesh pink, tinged with salmon, very delicate shade.

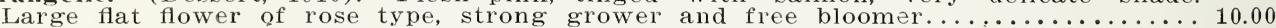

Walter Faxon. (Richardson). Uniform pure bright rose; very distinct delicate color.

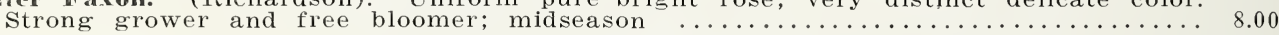

FROI OHIO

I received the two peonies I ordered recently and very good looking roots they were too. I never saw so many fine fibrous roots in any peony root as there were on tke Sarah Bernhardt.
2.50

the

\section{FROM ARITANSAS}

The Therese peony you sent me last fall is rather remarkable for a one-year old plant; it now has eight strong shoots six or eight inches high. 


\section{SINGLE and JAPANESE}

Isani-Gidui. (Japan). Very large pure white single flower, with silky broad petals, big central tuft of golden yelpetals, big central tuft of golden yellow stamens or filamentous petals; splendid variety of marvelous beauty 15.00

Iarguerito Dessert. (Dessert, 1913). Pure white, entirely powdered and splashed with carmine; central tuft of golden stamens; one of the most exquisite varieties. Very large single

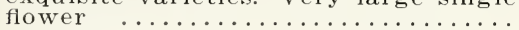

Perle Blanehe. (Dessert). Pure white, cup-shaped flowers, with a golden

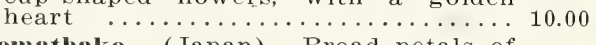

'Tomatbako. (Japan). Broad petals of bright soft pink, large center of yellow stamens.............. 10.00

Tokio. (Japan). Color, old rose; very large, showing a central tuft of golden filamentous petals. Beautiful variety, strong grower, and free

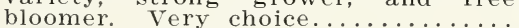

Venise. (Dessert). Bright lively pink, slightly tinged with carmine, central tuft of golden stamens; large flower. Divisions............

Vesure. (Dessert). Large brilliant dark red flowers with metallic reflex

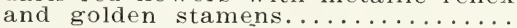

Ieso. (Japan). Guard petals pure white, narrow central petals white tinged straw yellow, and tipped with a little carmine point.........

6.00

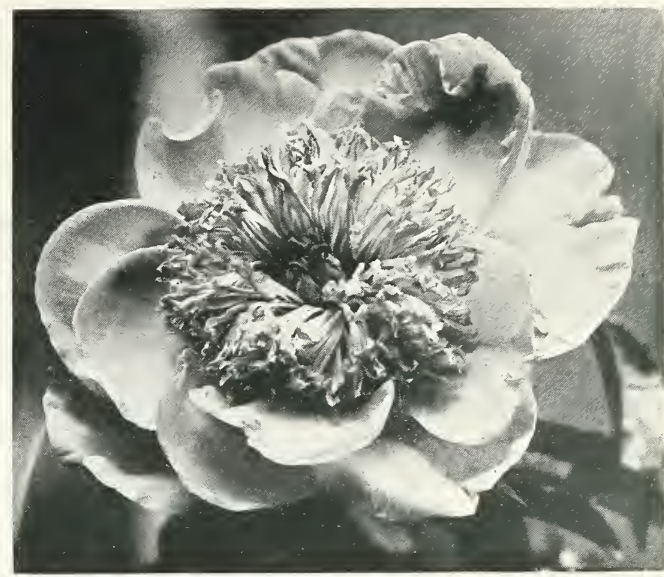

Tokio, s imehes in Diameter

FTOUI PENNSYLVANIA

The peony root Sarah Bernhardt was received today in very excellent condition. I wish to thank you very kindly for the fine large root you have sent; if I do not succeed with it, I you have sent; if I do not succeed with it, root.

\section{Symposium on a General List of Peonies}

A consensus of opinion of the Leading Peony Growers on the rating of varieties as published in the Peouy Bulletin, No. 7 , gives the hish place to many of tle Peonies in our list. We have 10 of the 12 ranking 9 or more in a sealo of 10 on a basis of 20 votes. In a wroup of second excellence we also have all but iwo of the 33.

The Twelve Peouies ranking nine or more on a scale of ten, are as follows:

9.7. Le Cygne, Solange, Therese.

9.3. Festiva Maxima, Lady Alex. Duff, La France.

9.2. Mon. Jules Elie. Sarah Bernhardt.

9.1. Baroness Schroeder, Mme. Emile Lemoine.

9.0. Marie Crousse, Milton Hill.

Secretary Saunders well says: "Each of us will regret in it the absence of some of his favorites. Of course 20 is an arbitrary number; but we need one large enough to ensure a wide dissemination of the variety, and also large enough to eliminate the effect of a possible erratic vote. Accepting 18 votes as a basis we get in Mme. Jules Dessert and Tourangelle $9 . \pm$ and Walter Faxon 9.2.

Applying the same principle of 20 votes as a basis to the group 9 down to 8 , we find the following as constituting a group of second excellence:

8.9. Karl Rosenfield, Rosa Bonheur.

8.8. Albatre. Avalanche.

8.7. Alsace Lorraine, Jas. Kelway, Mons. Martin Cahusac, Mont Blanc.

8.6. Asa Gray, Grandiflora, Marguerite Gerard, Marie Lemoine.

8.5. Albert Crousse, Claire Dubois, Eugenie Verdier, Mme. Aug. Dessert, Mme. Emile Galle, Venus.

8.4. Adolph Rosseau, Germaine Bigot, Livingstone, Mme. Calot, M. Dupont.

8.3. Duchess de Nemours, Eugene Verdier, Felix Crousse.

8.2. Augustin d'Hour, La Tendresse, Marie Jaquin, Primevere, Triomphe de l'Exposition de Lille.

8.1. Aurore.

8.0. Mme, Geissler, Modeste Guerin, Mme, Ducel.

Accepting 15 votes as a basis brings into this list several good ones:

8.6. Reine Hortense, 18 votes.

8.4. Mlle. Rosseau, 16 votes

8.3. Mine. Boulanger, 16 votes; Octavie Demay, 18 votes; La Rosiere, 18 votes.

8.1. Marcelle Dessert and Mme. de Treyeran, 15 votes; La Perle, 19 votes

The following list on a basis of 17 to 35 votes scoring 7.9 should not be overlooked:

Couronne d'Or, 35; Mme. de Verneville, 30; Mme. de Galhau and Mme. Forel, 20; Mme.

Crousse, 21; Lamartine, 19; Philomele, 18; Grandiflora, 17. 


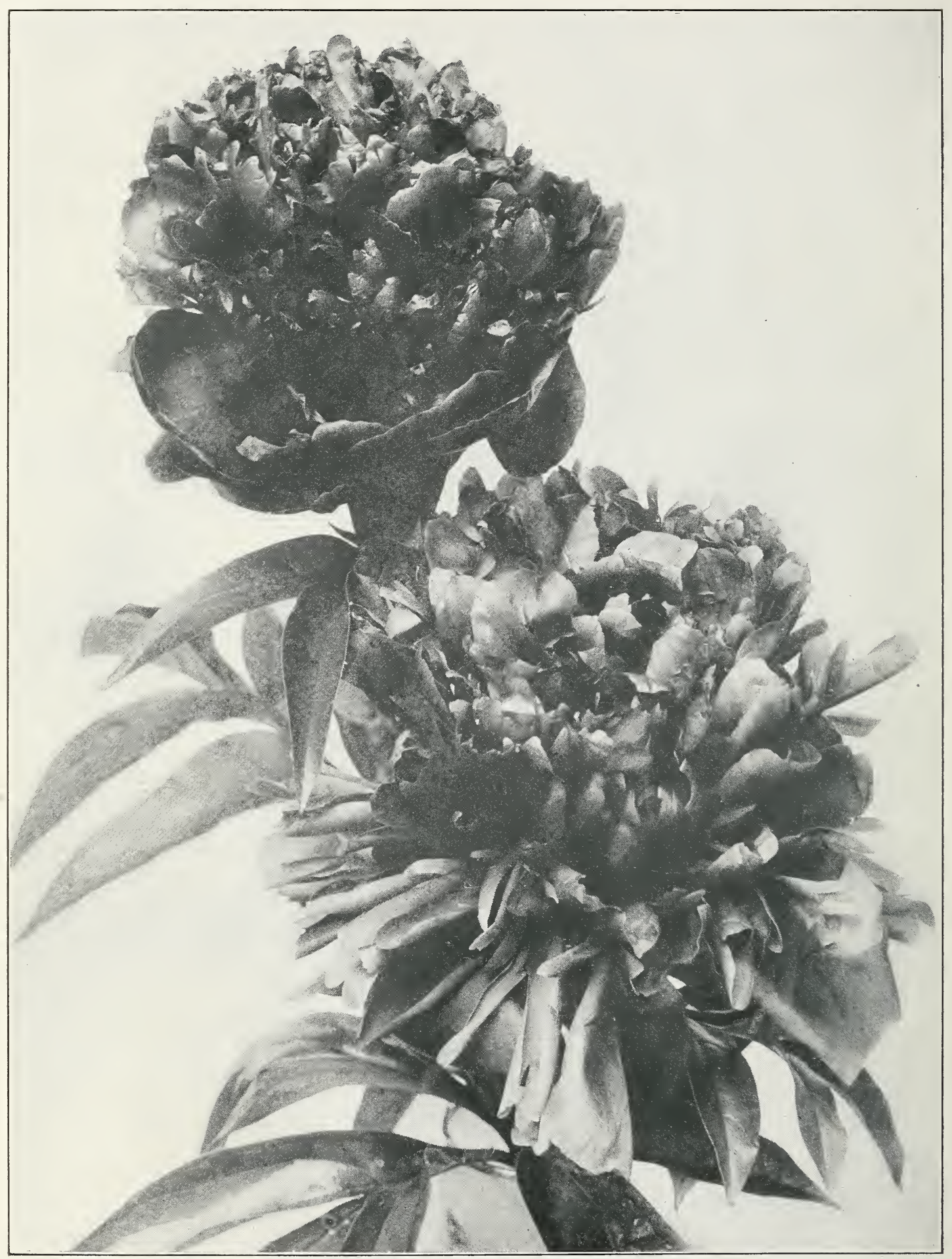

"Mons. Martin Cahuzac," ahove, the darkest of all Peonies.

"Karl Rosenfield," below, one of the best very dark Peonies. 